\title{
Structure, Subunit Composition, and Molecular Weight of RD-114 RNA ${ }^{1}$
}

\author{
HSING-JIEN KUNG, JAMES M. BAILEY, NORMAN DAVIDSON,* MARGERY O. NICOLSON, \\ AND ROBERT M. MCALLISTER \\ Department of Chemistry, California Institute of Technology, Pasadena, California $91125,{ }^{*}$ and Department of \\ Pediatrics, University of Southern California School of Medicine, Childrens Hospital of Los Angeles, Los \\ Angeles, California 90054
}

Received for publication 9 April 1975

The properties and subunit composition of the RNA extracted from RD-114 virions have been studied. The RNA extracted from the virion has a sedimentation coefficient of $52 S$ in a nondenaturing aqueous electrolyte. The estimated molecular weight by sedimentation in nondenaturing and weakly denaturing media is in the range $5.7 \times 10^{6}$ to $7.0 \times 10^{6}$. By electron microscopy, under moderately denaturing conditions, the $52 \mathrm{~S}$ molecule is seen to be an extended single strand with a contour length of about $4.0 \mu \mathrm{m}$ corresponding to a molecular weight of $5.74 \times 10^{6}$. It contains two characteristic secondary structure features: (i) a central Y-or T-shaped structure (the rabbit ears) with a molecular weight of $0.3 \times 10^{6}$; (ii) two symmetrically disposed loops on each side of and at equal distance from the center. The $52 S$ molecule consists of two half-size molecules, with molecular weight $2.8 \times 10^{6}$, joined together within the central rabbit ears feature. Melting of the rabbit ears with concomitant dissociation of the $52 S$ molecule into subunits, has been caused by either one of two strongly denaturing treatments: incubation in a mixture of $\mathrm{CH}_{3} \mathrm{HgOH}$ and glyoxal at room temperature, or thermal dissociation in a urea-formamide solvent. When half-size molecules are quenched from denaturing temperatures, a new off-center secondary structure feature termed the branch-like structure is seen. The dissociation behavior of the $52 \mathrm{~S}$ complex and the molecular weight of the subunits have been confirmed by gel electrophoresis studies. The loop structures melt at fairly low temperatures; the dissociation of the $52 S$ molecule into its two subunits occurs at a higher temperature corresponding to a base composition of about $63 \%$ guanosine plus cytosine. Polyadenylic acid mapping by electron microscopy shows that the $52 S$ molecule contains two polyadenylic acid segments, one at each end. It thus appears that 52S RD-114 RNA consists of two $2.8 \times 10^{6}$ dalton subunits, each with a characteristic secondary structure loop, and joined at the 5 ' ends to form the rabbit ears secondary structure feature. The observations are consistent with but do not require the conclusion that the two $2.8 \times 10^{6}$ dalton subunits of $52 S$ RD-114 RNA are identical.

The organization of RNA extracted from RNA tumor viruses has been extensively studied during the past few years. In most instances, the principal RNA species isolated from the virion is a complex sedimenting at 60 to $70 \mathrm{~S}$ with a molecular weight of approximately $10^{7}$. Upon exposure to denaturing conditions, this complex dissociates into a major component with a sedimentation coefficient of about $35 \mathrm{~S}$ (and a molecular weight of $2.5 \times 10^{6}$ to $3.3 \times$ $10^{6}$ ) and into several small (4 to $10 S$ ) species.

${ }^{1}$ Contribution no. 5076 from the Department of Chemis try, California Institute of Technology, Pasadena, Calif. 91125.
In earlier papers we described our preliminary electron microscope characterization of total RNA from the endogenous feline $\mathrm{C}$ type virus, RD-114 $(9,10)$. We reported that the major RNA component, when mounted for electron microscopy by procedures which extend the RNA sufficiently well for tracing, is a molecule of $3.7 \mu \mathrm{m}$ contour length, corresponding to a molecular weight of $5.0 \times 10^{6}$. Furthermore, these molecules all contained a characteristic Y- or T-shaped secondary structure feature near the middle of the molecule. Such an observation is consistent with the hypothesis that all $5 \times 10^{6}$ dalton molecules are identical in sequence. However, the molecular weight of 
this molecule is quite high in comparison to that of the major RNA component of other RNA tumor viruses. The presence of the characteristic secondary structure feature at the middle of the molecule therefore raises the possibility that the $5.0 \times 10^{6}$ dalton molecule is not a continuous polynucleotide chain but is instead two approximately $2.5 \times 10^{6}$ dalton molecules joined by base pairing within the central secondary structure feature.

We were initially inclined to reject this hypothesis because in electron microscope spreadings of RNA molecules exposed to rather stongly denaturing conditions, we were able to identify full length $(3.7 \mu \mathrm{m})$ molecules in which the secondary structure feature appeared to be absent. We stated at the time that we felt that this evidence was not conclusive since only $50 \%$ of the full length molecules were in this class.

We have accordingly continued these studies and searched for denaturing conditions which would either denature the secondary structure feature in all molecules or cause dissociation into smaller subunits. Our further electron microscope, sedimentation, and gel electrophoresis investigations of the structure subunit composition of RD-114 RNA are reported here.

\section{MATERIALS AND METHODS}

Virus and RNA preparations. Sindbis virus RNA was prepared as previously described (6). RD-114 virus was grown as described by Filbert et al. (3). Viruses were purified by isopycnic banding in a 24 to $48 \%$ sucrose gradient in NTE buffer $(0.1 \mathrm{M} \mathrm{NaCl}$, $0.01 \mathrm{M}$ Tris, $\mathrm{pH}$ 7.2, $0.001 \mathrm{M}$ EDTA) in an SE50.1 tube at $44 \mathrm{~K} \mathrm{rpm}$ for $3 \mathrm{~h}$ at $4 \mathrm{C}$. Virus fractions were pooled and treated with self-digested Pronase $(\sim 500$ $\mu \mathrm{g} / \mathrm{ml}$ ) in the presence of $0.5 \%$ sodium dodecyl sulfate for $30 \mathrm{~min}$ at $37 \mathrm{C}$. The solution was then adjusted to $1 \%$ sodium dodecyl sulfate and $1 \%$ mercaptoethanol. After repeated phenol extraction, the RNA samples were ethanol precipitated and resuspended in $\sim 100 \mu \mathrm{l}$ of NTE solution. In several experiments, the Pronase step was omitted and identical results were obtained. Rous sarcoma virus was a gift from Peter Vogt. HeLa 28S rRNA was generously provided by James Casey.

Sedimentation. (i) NTE-sucrose gradient. A solution $(100 \lambda)$ of phenol-extracted ${ }^{~} \mathrm{H}$-labeled RD-114 RNA (in NTE) was layered directly onto a 5-ml 10 to $30 \%$ sucrose gradient in NTE buffer. Centrifugation was carried out in an SW50.1 rotor at $45 \mathrm{~K} \mathrm{rpm}$ at $4 \mathrm{C}$ for $1.75 \mathrm{~h}$. Sindbis RNA and $28 S$ HeLa rRNA were run in parallel as external markers.

(ii) Glyoxal-sucrose gradient. The phenolextracted ${ }^{3} \mathrm{H}$-labeled RD-114 RNA was dialyzed against $1 \mathrm{M}$ glyoxal in $0.01 \mathrm{M}$ phosphate buffer, $\mathrm{pH}$ 7.0 , for $1 \mathrm{~h}$ at $37 \mathrm{C}$, then dialyzed against $0.1 \mathrm{M}$ glyoxal in the same buffer for approximately $30 \mathrm{~min}$ at $4 \mathrm{C}$, all as previously described $(6,10)$. The sample thus treated was sedimented through a 10 to $30 \%$ sucrose gradient in the presence of $0.1 \mathrm{M}$ glyoxal, 0.01 $\mathrm{M}$ phosphate buffer, $\mathrm{pH} 7.2$, at $4 \mathrm{C}, 45 \mathrm{~K} \mathrm{rpm}$ for $5 \mathrm{~h}$ in an SW50.1 rotor. The peak fractions were used for electron microscope studies. Sindbis and Rous sarcoma virus RNAs were similarly treated and run in parallel as external markers.

(iii) Low salt-sucrose gradient. Phenol-extracted RD-114 RNA samples were incubated in 50\% formamide and $50 \%$ NTE at $37 \mathrm{C}$ for $10 \mathrm{~min}$. This treatment was designed to expose the hidden nicks of the RNA complex so as to give better fractionation. After removal of the formamide by dialysis at $4 \mathrm{C}$, RNA samples were loaded onto a 10 to $30 \%$ sucrose gradient containing $1 \mathrm{mM}$ Tris, $0.2 \mathrm{mM}$ EDTA, pH 7.2. Centrifugation was done in an SW50.1 rotor at $4 \mathrm{C}, 41$ $\mathrm{K}$ rpm for $3.5 \mathrm{~h}$. Peak fractions were pooled for other studies. Rous sarcoma virus 60 to $70 \mathrm{~S}$ RNA was similarly treated and run in parallel.

Electron microscopy. (i) Drop and high temperature spreading. In the present study, both the standard dish-spreading technique described by Davis et al. (1) and a drop-spreading technique were applied. The latter is a modification of the method described by Inman and Schnös (7). This technique requires only 1 to $5 \mathrm{ng}$ of RNA sample per spreading and is thus useful for studying small quantities and nucleic acids. It is also convenient in that it allows a spreading to be performed at a uniform high temperature in an oven. A Teflon block ( 10 by $10 \mathrm{~cm}$ by $1.2 \mathrm{~cm}$ ) which contains nine evenly spaced indentations (1.9 $\mathrm{cm}$ in diameter and $0.1 \mathrm{~cm}$ deep) was prepared. One drop of hypophase $(\sim 0.9 \mathrm{ml})$ was placed on one of the indentations. A Pasteur pipette with the narrow end sealed was inserted at an angle of $60 \mathrm{C}$ into the hypophase. Five microliters of the spreading solution was then applied through the outer surface of the narrow end of the Pasteur pipette onto the hypophase. Samples were picked up by touching a parlodioncoated grid to the surface of the drop within $30 \mathrm{~s}$ after spreading. The grid was then rinsed in $95 \%$ ethanol and rotary shadowed with platinum-palladium alloy.

For high temperature spreading, the Teflon block, the Pasteur pipette, the micropipettes, and the hypophase solution were all pre-equilibrated in an oven at the desired temperature for a least $30 \mathrm{~min}$. The RNA sample was heated for 30 to $60 \mathrm{~s}$ by immersing $10 \mu \mathrm{l}$ of spreading solution in a beaker of water pre-equilibrated in the oven. After heat treatment, $0.5 \mu \mathrm{l}$ of cytochrome $c$ solution $(1 \mathrm{mg} / \mathrm{ml})$ was added to the spreading solution, which was incubated in the hot water bath for another $30 \mathrm{~s}$. The spreading was quickly performed inside the oven with the door partially opened. The whole procedure from applying the spreading solution onto the hypophase until picking up the the film took approximately $30 \mathrm{~s}$.

For experiments to study the reassociated secondary structure, the spreading solution after heat treatment was quickly chilled on ice for 15 to $30 \mathrm{~s}$. The cytochrome $c$ was added and the solution was spread at room temperature.

Preparation for spreading. (i) Glyoxal-formamide method. RNA samples taken from the glyoxal-sucrose gradient peak fraction were diluted into the spreading solution to give a final concentration 
of 0.2 to $0.5 \mu \mathrm{g}$ of RNA per ml, $40 \%$ formamide, $0.1 \mathrm{M}$ Tris, $\mathrm{pH} 8.2,0.01 \mathrm{M}$ EDTA, and $\sim 30 \mu \mathrm{g}$ of cytochrome $c$ per $\mathrm{ml}$. Five microliters of the above spreading solution was used in one drop spreading, whereas $50 \mu \mathrm{l}$ was required in the conventional dish spreading. The hypophase contained $10 \%$ formamide, $0.01 \mathrm{M}$ Tris, pH 8.2, and 0.001 M EDTA.

(ii) Urea-formamide method. RD-114 RNA samples purified either by NTE or low salt-sucrose gradient centrifugation were used. The RNA samples were diluted into the spreading solution which contained $\sim 30 \mu \mathrm{g}$ of cytochrome $c$ per $\mathrm{ml}$ the desired concentration of urea-formamide and electrolyte.

The urea-formamide solvents used for electron microscope spreadings and for other denaturation studies were prepared as follows. Formamide was purified by recrystallization (11). A solution was

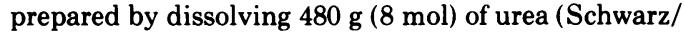
Mann ultra-pure grade) per liter of formamide. The conductance of this solution at $4 \mathrm{C}$ was $2 \times 10^{4} \mathrm{ohm}^{-1}$ $\mathrm{cm}^{-1}$, corresponding to an estimated electrolyte concentration of about $6 \mathrm{mM}$. We observed a 1.35-fold volume increase of the solution relative to the formamide. (Thus, the estimated concentrations of components in the solvent are $74 \%$ volume percent formamide and $5.9 \mathrm{M}$ urea, but this calculation is not used in characterizing the mixed urea, formamide, aqueous solutions as discussed below.) A solution prepared from $p$ volumes of the urea-formamide and $(100-p)$ volumes of aqueous solution is described as a $p \%(\mathrm{U}+\mathrm{F})$ solution. Unless otherwise specified, the aqueous electrolyte mixed with urea-formamide contained y $\mathrm{M}$ (TrisOH $+\mathrm{HCl}$ ), $\mathrm{pH} 8.5,0.1$ y $\mathrm{M}$ $\mathrm{Na}_{3}$ EDTA, with an estimated univalent cation concentration of $0.6 \mathrm{y} \mathrm{M}$ (based on $p \mathrm{~K}_{\mathrm{a}}$ of $\mathrm{TrisH}^{+}$of 8.1). The cation concentration, after dilution with ureaformamide, is reported for each experiment. Thus, for example, if the aqueous electrolyte had $y=0.24$, it contained $0.24 \mathrm{M}$ (TrisOH $+\mathrm{HCl}$ ), $0.024 \mathrm{M} \mathrm{Na}$ EDTA. If 40 volumes of this solution are mixed with 60 volumes of $(U+F)$, the final concentrations are $0.096 \mathrm{M}$ (Tris $\mathrm{OH}+\mathrm{HCl}$ ), $0.0096 \mathrm{M} \mathrm{Na}$ EDTA. Using 8.1 for the $p \mathrm{~K}_{\mathrm{a}}$ of $\mathrm{TrisH}^{+}$, we calculate $\left(\mathrm{TrisH}^{-}\right)=0.027 \mathrm{M}$.

The $100 \%(U+F)$ solvent had an absorbance at 275 $\mathrm{nm}$ of 0.5 . The denaturing power of the solvent was determined by optical melting experiments with calf thymus DNA in aqueous $\mathrm{U}+\mathrm{F}$ solutions containing the standard $0.06 \mathrm{M}$ electrolyte. We observe that

$$
T_{m}=73 \text { to } 0.65 \mathrm{C} \times p(\mathrm{U}+\mathrm{F}) .
$$

For electron microscope spreading from $(U+F)$ solutions, the hypophase was distilled water.

(iii) $\mathrm{CH}_{3} \mathrm{HgOH}$-glyoxal-formamide. We have also used a modification of the glyoxal technique which very effectively extends RNA. This procedure consists of the dialysis of the RNA against $1 \mathrm{M}$ glyoxal, 0.045 $\mathrm{M}$ sodium phosphate buffer, $\mathrm{pH} 8$, and $10 \mathrm{mM}$ methylmercuric hydroxide for $1 \mathrm{~h}$ at room temperature, followed by dialysis against $0.1 \mathrm{M}$ glyoxal, 0.045 $\mathrm{M}$ sodium phosphate buffer, and $0.05 \mathrm{M} \mathrm{NaCl}$ for $1 \mathrm{~h}$ at room temperature. Methylmercuric hydroxide is an effective denaturant that disrupts secondary structure features at room temperature $(5,13)$. The $\mathrm{CH}_{3} \mathrm{HgOH}-e x t e n d e d \mathrm{RNA}$ is easily fixed by glyoxal treatment and the $\mathrm{CH}_{3} \mathrm{HgOH}$ is then removed by the second dialysis against $\mathrm{NaCl}$ and glyoxal.

Agarose gel electrophoresis. Gels (10 by $0.8 \mathrm{~cm}$ ) were formed by melting 0.8 or $1.0 \%$ agarose in $\mathrm{E}$ buffer [0.05 $\mathrm{M}$ boric acid, $0.005 \mathrm{M}$ sodium borate $\left(\mathrm{Na}_{2} \mathrm{~B}_{4} \mathrm{O}_{7} \cdot 10 \mathrm{H}_{2} \mathrm{O}\right), 0.01 \mathrm{M}$ sodium sulfate, and 0.001 $\mathrm{M}$ EDTA, $\mathrm{pH}$ 8.2] and pouring the hot solution into an $11-\mathrm{cm}$ glass tube covered at one end with dialysis membrane. To conduct electrophoresis under conditions which are denaturing for RNA, methylmercuric hydroxide was added to the hot gel solution to the desired concentration. This technique will be described in detail elsewhere (J. Bailey, personal communication).

After solidification of the agarose, the gels were electrophoresed in a vertical tube apparatus containing electrophoresis $\mathrm{E}$ buffer in both the upper and lower chambers (the denaturing gel system used in this study does not require the presence of methylmercuric hydroxide in the buffer chambers). The samples were applied in $50 \lambda$ of a twofold dilution of $\mathrm{E}$ buffer containing $10 \%$ glycerol, and $5 \mathrm{mM} \mathrm{CH}{ }_{3} \mathrm{HgOH}$ for denaturing gel electrophoresis. For other experiments, the samples were applied in an electron microscope spreading solution containing $65 \%(\mathrm{U}+\mathrm{F}), 0.026 \mathrm{M}$ $\mathrm{NaCl}, 0.042 \mathrm{M}$ Tris, $\mathrm{pH} 7.9$, and $0.5 \mathrm{mM}$ EDTA (the total cation concentration is $0.06 \mathrm{M}$ ). Electrophoresis was performed at $5 \mathrm{~mA}$ per tube for periods of 2 to $3 \mathrm{~h}$ at room temperature. With radioactive RNA, the gels were sliced into $2-\mathrm{mm}$ fractions with a Mickel gel slicer and each fraction was incubated under $10 \mathrm{ml}$ of Aquasol for $16 \mathrm{~h}$. Radioactivity was determined in a Beckman LS-250 liquid scintillation counter. In several experiments unlabeled RNA was used, in which case bands were located by ethidium bromide staining (12). After electrophoresis gels were incubated in 1 $\mu \mathrm{g}$ of ethidium bromide, $0.5 \mathrm{M} \mathrm{NH}{ }_{4} \mathrm{Ac}$ (to remove $\mathrm{CH}_{3} \mathrm{HgOH}$ and enhance the dye binding) for $30 \mathrm{~min}$ and then examined by illumination with short wavelength ultraviolet light.

\section{RESULTS}

Sedimentation analysis of RD-114 RNA. The sedimentation properties of the highmolecular-weight RNA component extracted from the RD-114 virion has been studied in sucrose gradients in nondenaturing (high salt, NTE), moderately denaturing (low salt), and more strongly denaturing (glyoxal) solvents. There is a high-molecular-weight RD-114 RNA complex which has a sedimentation coefficient of $52 S$ relative to markers of Sindbis RNA ( $43 S$ ) and $\mathrm{HeLa}$ (28S rRNA) in the nondenaturing NTE solvent (Fig. 1). A plot of log $M$ versus $\log$ (distance sedimented) in these experiments is shown in Fig. 2. If a linear relation between these two variables is assumed, the molecular 

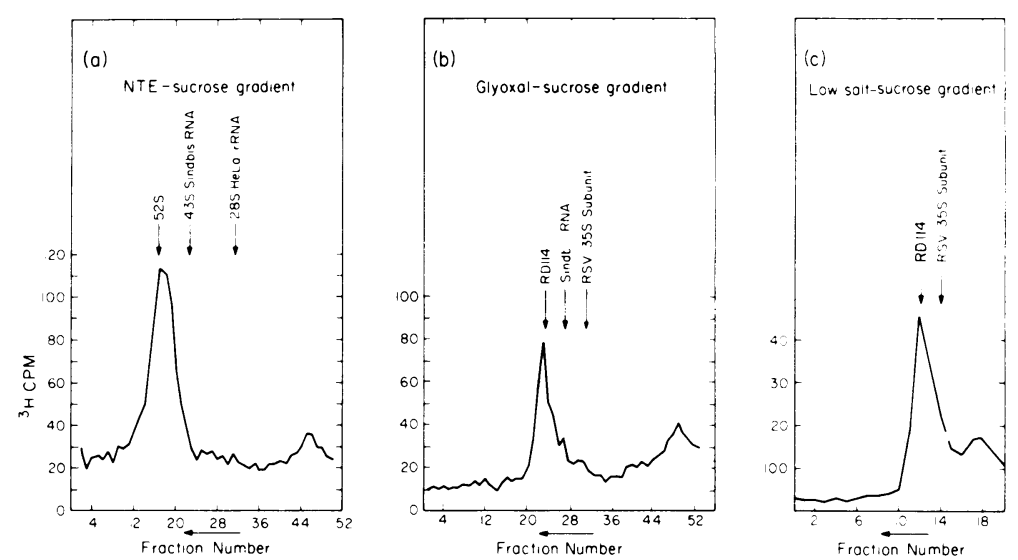

FIG. 1. Sedimentation profiles of RD-114 RNA as extracted from the virion in (a) NTE-sucrose gradient; (b) glyoxal-sucrose gradient; (c) low salt-sucrose gradient. All procedures are described in Materials and Methods.

weight of the RD-114 RNA complex is calculated by extrapolation to be $7.0( \pm 0.6) \times 10^{6}$.

Both the secondary structure and the molecular weight of a polynucleotide chain affect its sedimentation coefficient. We have therefore attempted to obtain a molecular weight estimate after disrupting the weaker secondary structure features of RD-114 RNA and of suitable marker RNAs. As a controlled denaturing agent, we have used the reagent, glyoxal. As described previously $(4,6,10)$ glyoxal, under proper conditions, binds quasi-irreversibly to guanosine residues and disrupts some of the weaker secondary structure features in a polynucleotide chain without causing dissociation of long well-paired duplex segments. The sedimentation profile of RD-114 (in this case with glyoxal-treated Sindbis RNA and Rous sarcoma virus $35 S$ subunits as reference RNAs) after glyoxal treatment is shown in Fig. 1b. After modification with glyoxal, RD-114 and Sindbis RNA both sediment at 0.30 times the velocity observed in the nondenaturing (NTE) solvent. A linear extrapolation of the $\log \mathrm{M}$ versus $\log$ (distance sedimented) plot for the two reference RNAs gives a molecular weight for RD-114 RNA of $5.7( \pm 0.3) \times 10^{6}$ (Fig. 2). As will be reported in the next section, this value is in good agreement with electron microscope measurements.

For preparative purposes we wished to use a weakly denaturing sedimentation medium which did not involve chemical modification of the RNA, but which would cause dissociation from the high-molecular-weight complex of any weakly bound, low-molecular-weight components and which might cause dissociation of molecules containing internal nicks. Our procedure was to incubate the RNA samples at $37 \mathrm{C}$

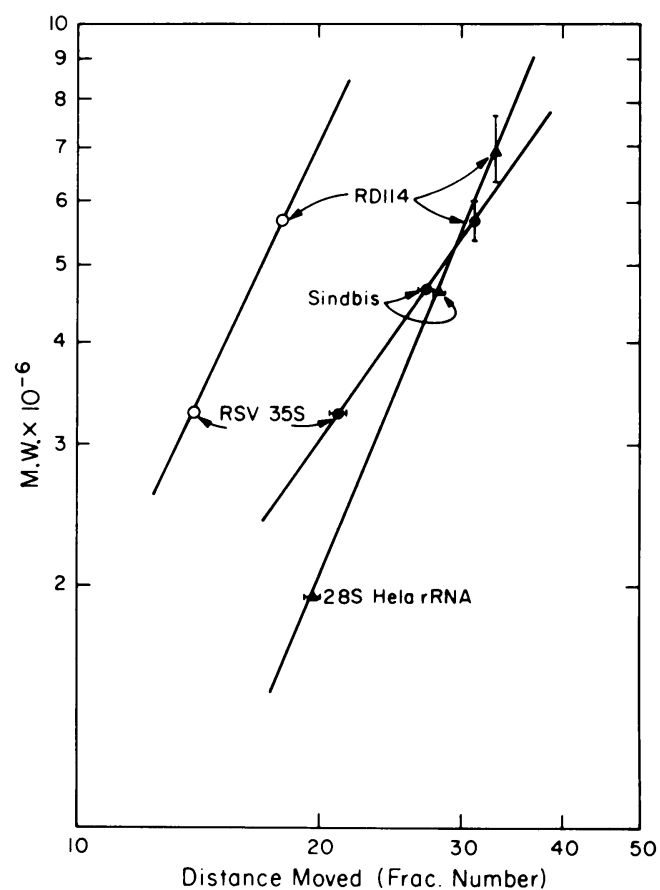

Fig. 2. Empirical relations between molecular weight and distance traveled as determined by sedimentation analysis in Fig. 1. Symbols: (வ) NTEsucrose gradient; (O) glyoxal-sucrose gradient; (O) low salt-sucrose gradient. Calibration curves for NTE and glyoxal-sucrose gradient were constructed from the results of marker RNAs and plotted on a log-log scale. (The molecular weight values used here for Sindbis and Rous sarcoma virus RNA have been presented previously $[6,10]$.) The molecular weight of $R D-114$ is estimated from these curves. The horizontal error bars correspond to \pm one fraction. The vertical error bars for the molecular weight of $R D-114$ are corresponding estimates of the extrapolation uncertainty. 
in $50 \%$ formamide, $50 \% \mathrm{NTE}$, and to sediment the product through a low salt $(1 \mathrm{mM}$ Tris, $\mathrm{pH}$ 7.0) aqueous sucrose gradient. The peak fractions from these preparative runs were pooled for other studies. As shown in Fig. 1c, RD-114 RNA again sediments at a position expected for a $5 \times 10^{6}$ to $6 \times 10^{6}$ dalton RNA species.

We presume that essentially the same highmolecular-weight complex is being observed by sedimentation in the three different systems described above. We refer to this entity as the 52S RD-114 RNA complex. It may be noted that incubation at $37 \mathrm{C}$ in $50 \%$ formamide, $50 \% \mathrm{NTE}$ causes dissociation of 60 to $70 S$ avian RNA tumor virus RNA into $35 S$ subunits $(10,14)$. However, the 52S RD-114 RNA is not dissociated by this treatment.

Electron microscope studies. We have studied the molecular weight, the secondary structure, and the subunit composition of the RD-114 52S RNA complex by electron microscopy in experiments in which the RNA is exposed to a set of conditions of increasing denaturing power. It may be recalled that single-strand RNA molecules are not well extended under the usual 40 to $60 \%$ formamide, $0.1 \mathrm{M}$ Tris electrolyte, spreading conditions that are effective for extending single-strand DNA (1).

Several different solvent systems that are effective for extending RNA have been used in the present studies. (i) Urea-formamide spreadings. A spreading solution containing urea, formamide, and a low electrolyte concentration is useful for extending RNA molecules under controlled denaturing conditions $(15,16)$. In the present instance, we have used a series of solutions with a fixed electrolyte concentration as described in Materials and Methods. When 52S RD-114 RNA is spread from $30 \%$ formamide $(0.06 \mathrm{M}$ univalent cations, no urea) it has a highly condensed structure (Fig. 3a), and the detailed topology of the molecules cannot be discerned. In spreadings from $55 \%$ (U + F) (with $0.12 \mathrm{M}$ univalent cations), the RNA is, in general, still very tangled. However, in some molecules, such as those shown in Fig. 3b, the secondary structure features described in detail below can be recognized. When the $(U+$ F) concentration is raised to $70 \%(0.06 \mathrm{M}$ cations), many of the molecules are sufficiently well extended so that they can be traced. There are two characteristic secondary structure features which are present in almost all of the full length traceable molecules: (i) a Y- (or T-) shaped structure located close to the middle, which we refer to as the rabbit ears (RE) structure, (ii) two symmetrically disposed loops, on each side of and at equal distances from the central RE feature. The micrograph in Fig. 3c illustrates several molecules spread from $70 \%$ $(\mathrm{U}+\mathrm{F})$. One is quite tangled but the $\mathrm{RE}$ can be recognized; in the other two, the RE and the loops can be seen.

If the RNA is spread from $80 \%(\mathrm{U}+\mathrm{F})(0.05$ $M$ cations), all of the molecules are extended and suitable for length measurements (Fig. 3d). A histogram of these length measurements is shown in Fig. 4a, with the number average length of $3.98 \pm 0.21 \mu \mathrm{m}$.

We believe that the molecule of molecular length $3.98 \mu \mathrm{m}$ with the $\mathrm{RE}$ and the two loops is the $52 S$ RD-114 RNA complex. The length measurements correspond to a molecular weight of about $5.7 \times 10^{6}$. However, we defer a detailed discussion of lengths and molecular weights and of the positions of the several secondary structure features until a later section.

Among full length molecules (shaded area in Fig. 4a) over $97 \%$ contained the RE. Of these, $46 \%$ had one loop and 28\% (including the molecule shown in Fig. 3d) had both loops at symmetrical positions. These observations, and others reported below, are consistent with the view that the two loops and the RE are native secondary structure features of $52 S$ RD-114 RNA. Spreading conditions, such as those used in Fig. 3d, which are useful for extending the molecules for good length measurements, are sufficiently denaturing to cause dissociation of about $50 \%$ of the loops but not the RE. It should also be noted that the RE in RD-114 RNA was described in our preliminary papers $(8,9)$, but the reproducible loop structures were not recognized.

We wished to ask whether the RD-114 RNA molecule of molecular weight $5.7 \times 10^{6}$ is one continuous polynucleotide chain or consists of two subunits, each of molecular weight approximately $2.8 \times 10^{6}$, held together by some sort of cohesion within the RE. We therefore sought procedures to expose the RNA to strongly denaturing conditions while minimizing the risk of covalent chain breakage.

As reported in this and following sections, we have found two different denaturing treatments which cause the $52 S \mathrm{RD}-114 \mathrm{RNA}$ molecule to be dissociated into two half-size molecules, with a concomitant disappearance of the RE.

The structure of the RNA was observed when spread from $65 \%(\mathrm{U}+\mathrm{F})(0.06 \mathrm{M}$ univalent cations), onto distilled water at several elevated temperatures as described in Materials and Methods. Below $50 \mathrm{C}, 3.98 \mu \mathrm{m}$ molecules with an $\mathrm{RE}$ are observed. At $60 \mathrm{C}$ and above, many half-size molecules without an RE are observed. 

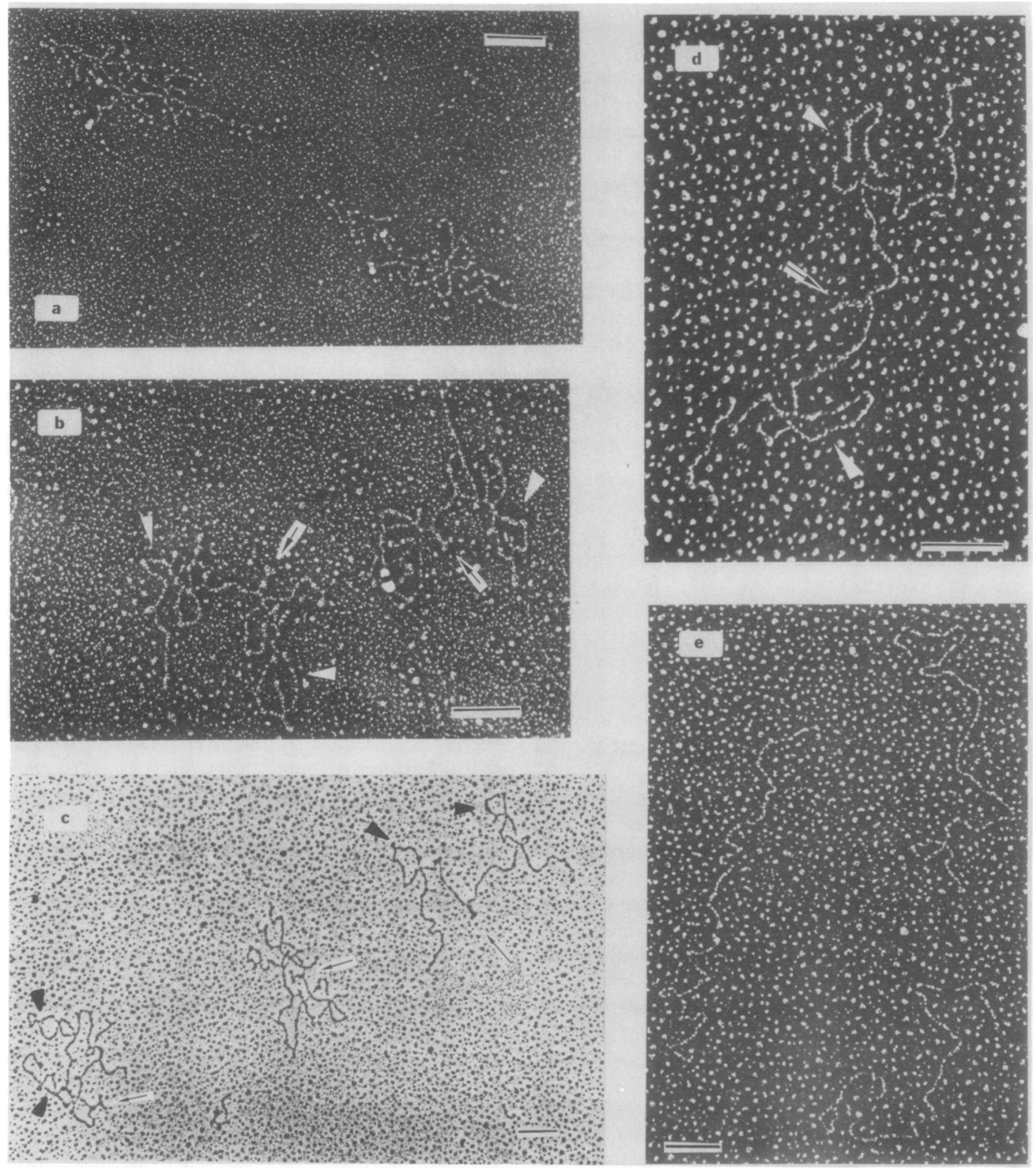

Fig. 3. Electron micrographs of RD-114 spread by the urea-formamide technique. (a) In $30 \%$ formamide (no urea, $0.06 \mathrm{M}$ cations $)$ at $20 \mathrm{C} ;(\mathrm{b})$ in $55 \%(U+F)(0.12 \mathrm{M}$ cations $)$ at $20 \mathrm{C} ;(\mathrm{c})$ in $70 \%(U+F)(0.06 \mathrm{M}$ cations $)$ at $20 \mathrm{C} ;(d)$ in $80 \%(U+F)(0.05 \mathrm{M}$ cations $)$ at $20 \mathrm{C} ;(e)$ in $65 \%(U+F)(0.06 \mathrm{M}$ cations $)$ at $80 \mathrm{C}$. Arrows indicate the central $R E$ structure. Triangles point to the loop features. The urea-formamide and high temperature spreading technique are described in Materials and Methods. The length marker is $0.2 \mu \mathrm{m}$.

A histogram of the size distribution from an $80 \mathrm{C}$ experiment is shown in Fig. 4b. The average molecular length was $2.10 \mu \mathrm{m}$. Over $98 \%$ of the molecules observed were smooth and extended without any secondary structure feature, as shown in examples in Fig. 3e. About 2\% of the molecles were undissociated, with a length of about $4.0 \mu \mathrm{m}$ and an RE.
A solution of RD-114 RNA in the urea-formamide solvent was heated to 60 or $80 \mathrm{C}$, quenched in ice water, and promptly spread at room temparature. The resulting molecules were half size without an RE. The length distribution for these molecules presented in Fig. 4c corresponds to an average length of 1.97 $\mu \mathrm{m}$, in good agreement with the lengths ob- 
served in the high temperature spreadings. After heating and quenching, there was a new secondary structure feature which is illustrated in the micrographs in Fig. 5. The structure can be decribed as having an unsymmetrical branch over its stem, and is referred to as a branch-like structure (BLS). It is morphologically quite different in appearance from the RE. The contour length of this feature (traced assuming it is duplex) is $0.31 \pm 0.06 \mu \mathrm{m}$ and it occurs at a distance of $0.21 \pm 0.05 \mu \mathrm{m}$ from one end of the otherwise linear $1.97-\mu \mathrm{m}$ molecules. About $30 \%$ of the half-size molecules in the quenched sample had the BLS; the remaining $70 \%$ were extended, although slightly knobby.

Between 1 and $2 \%$ of the molecules were not dissociated by heating to $60 \mathrm{C}$ and quenching and were full size $(4.0 \mu \mathrm{m})$ with an RE. A representative molecule is shown in Fig. 5a. It contains two BLS, symmetrically disposed at a distance of $0.2 \mu \mathrm{m}$ from the RE. This result strongly supports the model that RD-114 RNA consists of two chains of molecular weight $2.8 \times 10^{6}$ joined together within the $\mathrm{RE}$. The BLS appears to be a base-paired structure due to sequences extending from a point close to $\mathrm{RE}$ to a point slightly within the loop structure. It is formed after quenching when the loop structures seen in the native $52 S$ RNA complex are dissociated.

(ii) Glyoxal-formamide spreading. Reaction with glyoxal under the conditions in Materials and Methods modifies single-strand RNA so that it is well extended in formamide spreadings, but does not cause denaturation of wellmatched duplex structures. We prefer glyoxal spreading to urea-formamide spreading for quantitative length measurements because in our hands it gives more constant and narrow length distributions for a homogeneous RNA.

Glyoxal-treated RD-114 RNA from the peak fractions of the glyoxal-sucrose gradient (Fig. 1b), when examined in the electron microscope under standard $50 \%$ formamide spreading conditions, appears as a linear extended filament with the RE close to the middle of the molecule. The loop structures observed in the urea-formamide spreads were also observed in glyoxal spreadings. An electron micrograph of a full length molecule with the $\mathrm{RE}$ and the two loops, symmetrically disposed relative to the $\mathrm{RE}$, is shown in Fig. 6a. As shown in the histogram in Fig. 7a, the size distribution of the RNA molecules is reasonably homogeneous with a number average length of $4.27 \pm 0.17 \mu \mathrm{m}$. We use Escherichia coli $23 S$ rRNA as an external length standard $\left(\langle\mathrm{L}\rangle_{n}=0.80 \pm 0.04 \mu \mathrm{m}\right.$, molecular weight $\left.=1.08 \times 10^{6}\right)$ and calculate the molecu-

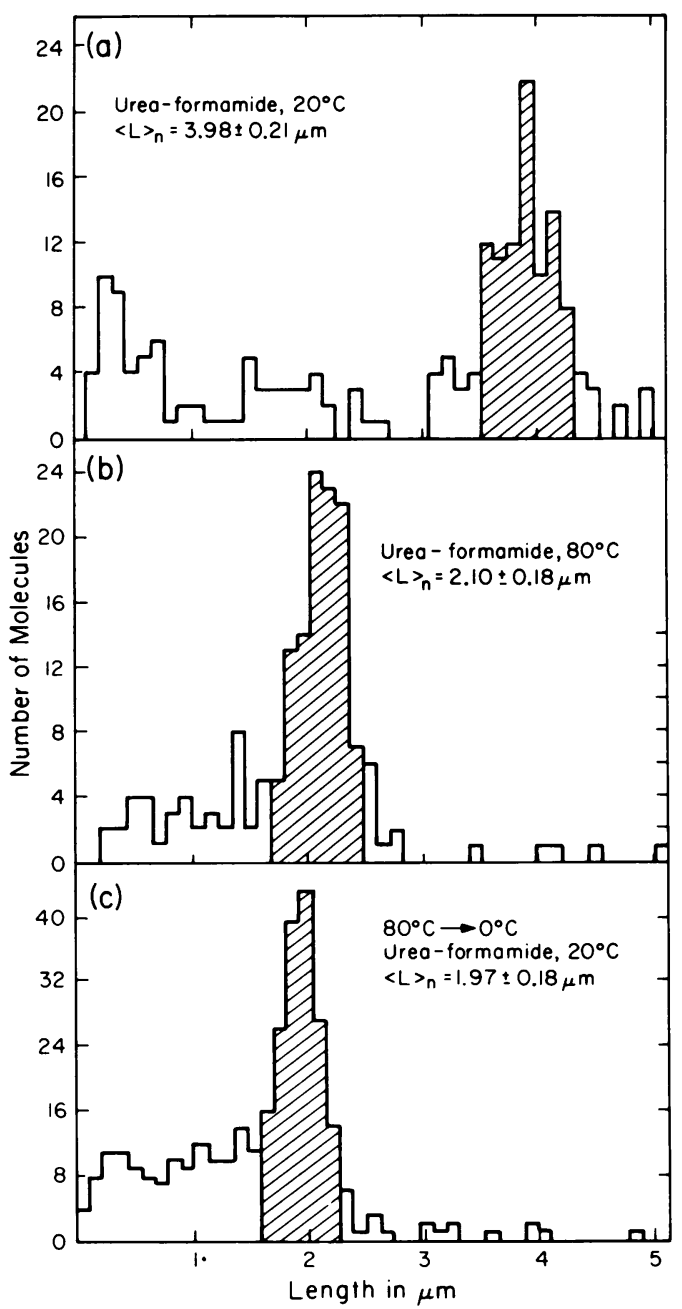

FIG. 4. Histogram of the length distribution of $R D-114$ RNA spread by the urea-formamide technique. (a) RD-114 RNA spread in $80 \%(U+F)(0.05$ $M$ cations) at $20 \mathrm{C}$; (b) RD-114 RNA spread in $65 \%$ (U $+F)(0.06 \mathrm{M}$ cations) at $80 \mathrm{C}$; (c) RD-114 RNA in $65 \%$ $(U+F)(0.06 M$ cations $)$, heated at $80 \mathrm{C}$, chilled on ice, and spread at $20 \mathrm{C}$. The number average lengths were calculated from molecules in the shaded area.

lar weight of this RD-114 molecule as $5.74 \pm$ $0.23 \times 10^{6}$. In these length measurements the RE structure is treated as entirely duplex, and its single-strand length measured by going back and forth over the entire feature.

Over $97 \%$ of the full length molecules (defined by the shaded area in Fig. 7a) contain the RE. By tracing up and down, as indicated above, its single-strand length was estimated as $0.21 \pm$ $0.04 \mu \mathrm{m}$. Approximately $28 \%$ of the glyoxaltreated full length molecules contain two symmetrical loops, $52 \%$ contain one loop, and the 

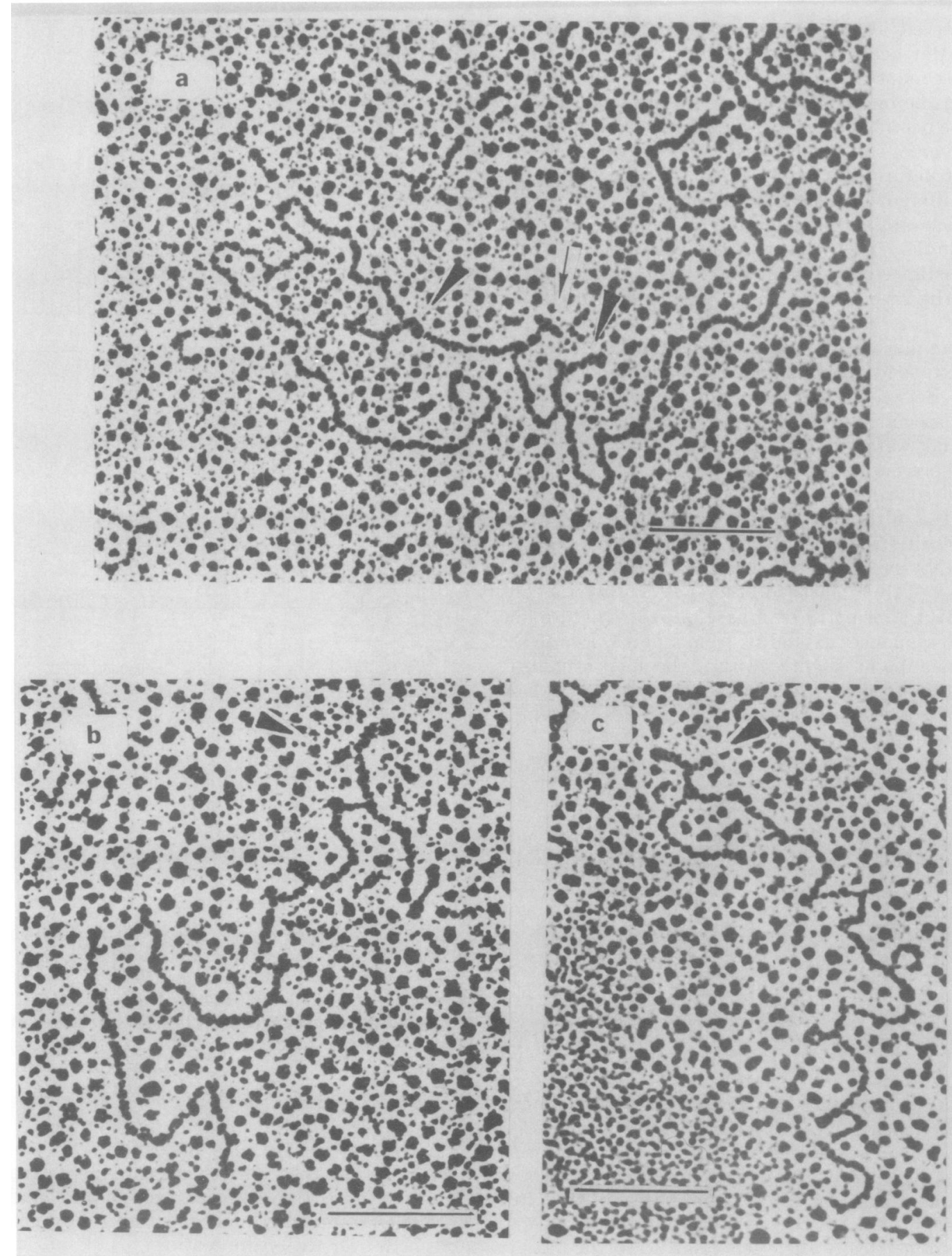

Fig. 5. Electron micrographs of heated and chilled RD-114 RNA spread by urea-formamide technique. $52 S$ $R D-114 R N A$ samples in $65 \%(U+F)$ were heated to $80 C$, then quickly quenched on ice and spread at $20 C$. (a) An undissociated $5.7 \times 10^{\circ}$ dalton $R D-114 R N A$. The molecule contains the $R E$ (arrow) and the two BLS (triangles) symmetrically located on each side of the RE. (b and c) Each show a $2.8 \times 10^{6}$ dalton RD-114 RNA with the BLS (triangle). The length marker is $0.2 \mu \mathrm{m}$. 


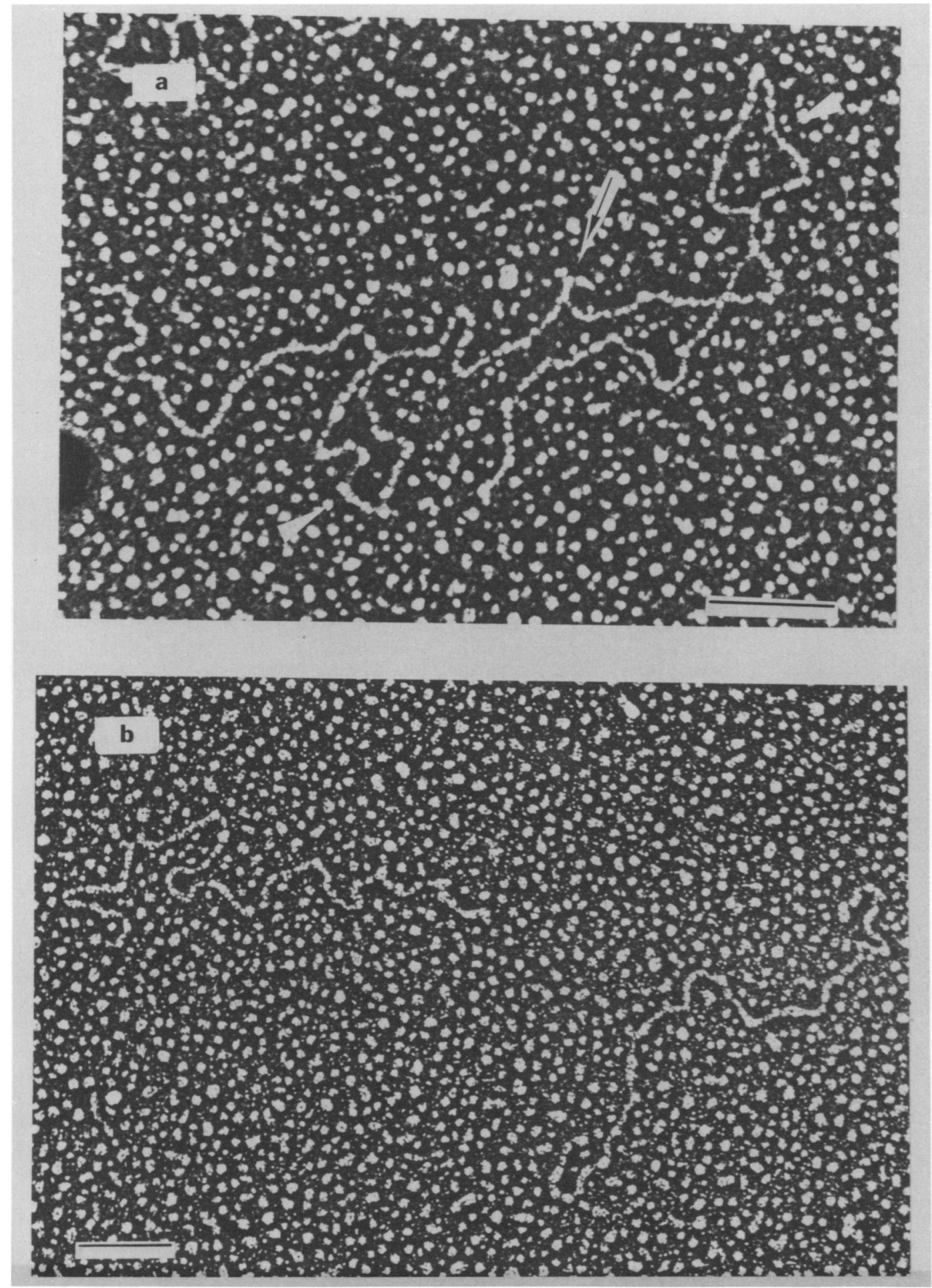

Fig. 6. Electron micrographs of RD-114 RNA spread by the glyoxal-formamide technique. (a) Glyoxaltreated $\mathrm{RD}-114 \mathrm{RNA} ;(\mathrm{b}) \mathrm{CH}, \mathrm{HgOH}$-glyoxal-treated $\mathrm{RD}-114 \mathrm{RNA}$. An arrow indicates the central RE structure. Triangles point to the two loop features. Procedures for RNA treatment and electron microscopy spreading are detailed in Materials and Methods. The length marker is $0.2 \mu \mathrm{m}$. 

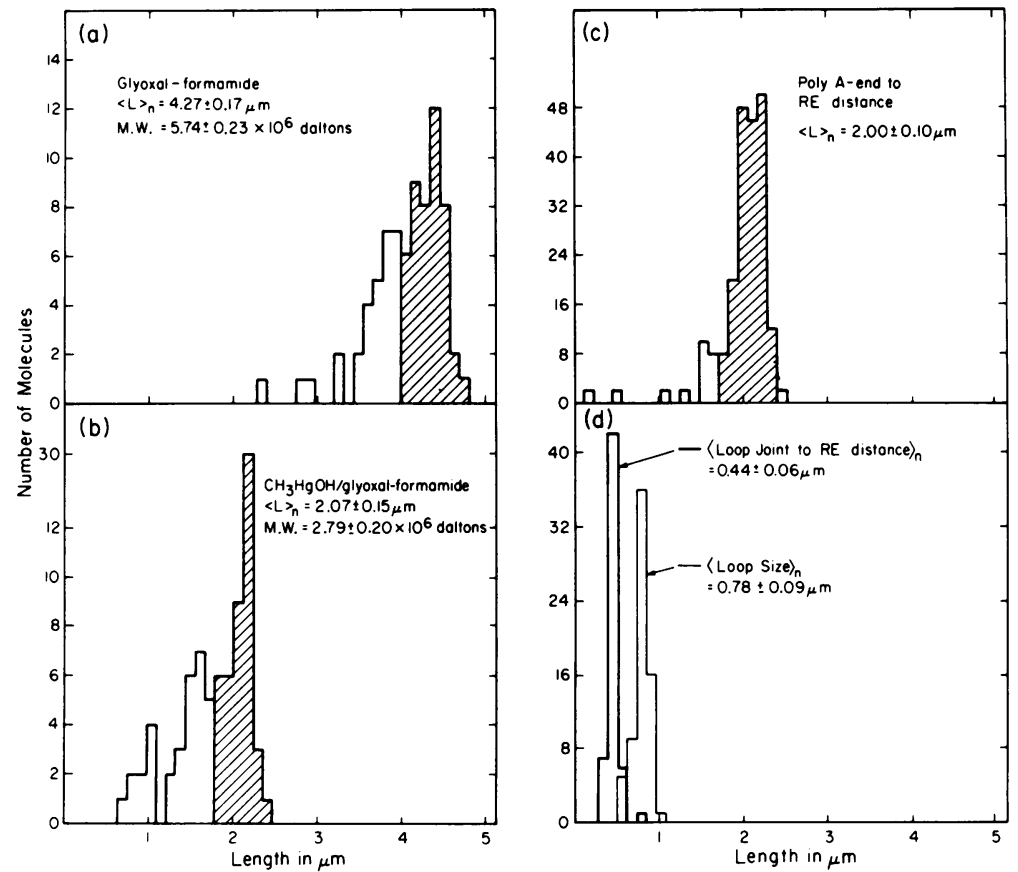

FIG. 7. Histogram of the length distribution of RD-114 RNA as studied by the glyoxal-formamide and $\mathrm{CH}_{3} \mathrm{HgOH}$-glyoxal-formamide techniques. (a) The total length of glyoxal-treated RD-114 RNA; (b) the total length of $\mathrm{CH}, \mathrm{HgOH}$-glyoxal-treated $52 \mathrm{~S} \mathrm{RD}-114 \mathrm{RNA}$ from a low salt gradient; (c) end to central RE structure distance of glyoxal-treated RD-114 RNA; (d) the loop joint to central RE structure distance and the loop size of glyoxal-treated RE-114 RNA.

remaining $20 \%$ do not have any. As shown by the histogram in Fig. $7 \mathrm{~d}$, these loops are mapped reproducibly at a distance $0.44 \pm 0.06$ $\mu \mathrm{m}$ from the RE and have a homogeneous loop length of $0.78 \pm 0.09 \mu \mathrm{m}$. One would suspect that the loop structures are due to short complementary sequences at the base of the loop. If so, the length of this duplex segment appears to be less than 200 nucleotide pairs and thus too short to be positively identified as such in the electron micrographs. (One can, however, imagine that such a duplex segment does exist on examining micrographs such as that shown in Fig. 6a.) The observation that not all molecules contain the loop structure suggests that the glyoxal denaturing conditions frequently cause denaturation of the short sequence of base pairs involved.

Thus, the results from the glyoxal spreadings confirm the structures observed in urea-formamide spreadings and support the view that $52 S$ RD-114 RNA isolated either by NTE gradients or by glyoxal gradients has essentially the same structure; i.e., a molecule of molecular weight $5.7 \times 10^{6}$, with the central RE structure and the two symmetrically disposed loop structures.

We wish to ask whether the RE is actually in the center or slightly off-center of the molecule. Let $L_{2}$ and $L_{1}$ be distance from hypothetical left and right ends of an asymmetrical molecule of molecular weight $5.7 \times 10^{6}$ with an RE feature close to but not necessarily at the center. We cannot a priori distinguish $L_{2}$ from $L_{1}$ for any molecule measured. We have calculated the root mean squeare value of the observed distribution of values of the intrinsically positive (and measurable) quantity, $\left|L_{2}-L_{1}\right|$, and find that it is $0.16 \mu \mathrm{m}$. For the same sample, the standard deviation of the distribution of values of $\left(L_{1}+L_{2}\right)$ was measured as $0.17 \mu \mathrm{m}$. If the RE were at the center of the molecule, the average value of the unobservable quantity $\left(\mathrm{L}_{2}-\mathrm{L}_{1}\right)$ would be zero and the root mean square value of $\left|L_{2}-L_{1}\right|$ is predicted to have the same value as the standard deviation in values of $\left(L_{1}+L_{2}\right)$. Thus, the observations support the view that the $\mathrm{RE}$ is at the center of the molecule.

(iii) Methylmercury-glyoxal spreadings. We wished to study the possible dissociation of the 52S RNA complex into its two subunits by a strongly denaturing treatment which did not involve elevated temperatures as in the ureaformamide thermal dissociation procedures. We 
have found that treatment with glyoxal in the presence of methylmercuric hydroxide is effective for this purpose.

$\mathrm{CH}_{3} \mathrm{HgOH}$ is a reversible denaturing reagent for nucleic acids because it reacts with the imino $\mathrm{NH}$ bonds of $\mathrm{G}, \mathrm{U}$, and $\mathrm{T}(5,13)$. It is a powerful denaturant. For example, at room temperature in $0.1 \mathrm{M} \mathrm{Na}_{2} \mathrm{SO}_{4}$ at $\mathrm{pH} 8.65$ Micrococcus luteus DNA which has a guanosine plus cytosine content of $72 \%$ is denatured at a $\mathrm{CH}_{3} \mathrm{HgOH}$ concentration of $2.9 \mathrm{mM}$ (5). We therefore anticipated that a sufficiently high concentration of $\mathrm{CH}_{3} \mathrm{HgOH}$ would denature any base pairing within the RE. As described in Materials and Methods the guanosine residues exposed by denaturation were then fixed in the nonhydrogen bonding state by treatment with glyoxal. Accordingly, 52S RD-114 RNA from a low salt gradient was treated with glyoxal in the presence of $10 \mathrm{mM}$ methylmercuric hydroxide, as described in Materials and Methods. Note that the methylmercuric hydroxide is removed before spreading. Figure $6 \mathrm{~b}$ shows an electron micrograph of the resulting RD-114 RNA molecules. As shown by the histogram in Fig. 7b, the resulting molecules have an average length of $2.07 \pm 0.15 \mu \mathrm{m}$ corresponding to a molecular weight of $2.8 \pm 0.2 \times 10^{6}$. They do not have any of the characteristic secondary structure features of the $5.7 \times 10^{6}$ dalton molecules. It therefore appears that the treatment described dissociates the $5.7 \times 10^{6}$ dalton RD-114 RNA into two subunits, each of molecular weight one-half the value for the starting molecule.

Gel electrophoresis of RD-114 RNA. The dissociation of $52 S$ RD-114 RNA into two halfsize subunits under suitable denaturation conditions has been confirmed by gel electrophoresis in several denaturing solvent systems.

We have recently developed a methylmercuric hydroxide-agarose gel system for electrophoresis under denaturing conditions. (Bailey and Davidson, personal communication). $52 S$ RD-114 RNA electrophoreses through a 1\% agarose gel containing $5 \mathrm{mM} \mathrm{CH}{ }_{3} \mathrm{HgOH}$ in the borate buffer electrolyte described in Materials and Methods at a velocity that is greater than that of Sindbis RNA but less than that of $28 S$ HeLa rRNA, and $23 S E$. coli rRNA. Typical gel patterns are illustrated in Fig. 8a. The $\log M$ versus (distance migrated) plot for several reference RNAs in this gel system is linear (Fig. 9) from which we interpolate the molecular weight of RD-114 RNA as $2.64( \pm 0.1) \times 10^{6}$. J. Bailey had observed that nicked circular duplex PM2 DNA is dissociated into single-strand components in the agarose gel-methylmercury system at methylmercury hydroxide concentrations greater than $3 \mathrm{mM}$. Therefore, the concentration of $5 \mathrm{mM}$ used in the RD-114 RNA experiments is strongly denaturing. The observed molecular weight is approximately one-half of that $\left(5.7 \times 10^{6}\right)$ of the $52 S$ RD-114 complex. Therefore we conclude that RD-114 RNA is dissociated into half-size subunits in the denaturing mercurial gel.

A more precise study of the thermal dissociation of 52S RD-114 RNA (molecular weight 5.7 $\times 10^{6}$ by electron microscopy and sedimentation analysis) into half-size subunits was made using a gel electrophoresis assay to observe dissociation. Labeled $52 S$ RD-114 RNA in the $65 \%(\mathrm{U}+\mathrm{F}), 0.06 \mathrm{M}$ cation solvent used for the thermal dissociation electron microscope studies, was heated to various temperatures, quenched on ice, and subjected to gel electrophoresis in the nondenaturing $E$ buffer at room temperature. It may be seen from the radioactivity profiles shown in Fig. $8 \mathrm{~b}$ that there is a pronounced increase in the distance migrated for a sample heated to $60 \mathrm{C}$ as compared to a sample heated to $55 \mathrm{C}$. Samples heated to 25 , 40 , and $50 \mathrm{C}$ all migrated with the same velocity as the $55 \mathrm{C}$ heat treatment; samples heated to 70 and $80 \mathrm{C}$ migrated like the $60 \mathrm{C}$ sample. Furthermore, a sample of unlabeled 52S RD-114 RNA from an NTE gradient was diluted directly into a twofold dilution of the $\mathrm{E}$ buffer, subjected to electrophoresis in the standard buffer, and located by ethidium bromide staining. Its position as shown in Fig. 8 is the same as that of the sample heated to $55 \mathrm{C}$. There is thus a structural transition with a marked increase in mobility between 55 and $60 \mathrm{C}$.

By interpolation from the values for the electrophoretic mobilities of HeLa $28 S$ rRNA and Sindbis RNA in the same gel system, the molecular weights of the low and high temperature forms of RD-114 RNA are estimated as 6.7 $\times 10^{6}$ and $4.2 \times 10^{6}$. These values are higher than the expected values of $5.7 \times 10^{6}$ and $2.8 \times$ $10^{6}$. A sample of RD-114 RNA was treated with $10 \mathrm{mM} \mathrm{CH}{ }_{3} \mathrm{HgOH}$ in $\mathrm{Na}_{2} \mathrm{SO}_{4}$, borate buffer, and then dialyzed against $0.1 \mathrm{M} \mathrm{NH} \mathrm{N}_{4} \mathrm{Cl}$ to remove the bound material and studied by electrophoresis in the nondenaturing gel. We believe, from the electrophoresis studies in 5 $\mathrm{mM} \mathrm{CH}{ }_{3} \mathrm{HgOH}$ that this treatment will cause dissociation of RD-114 RNA into $2.8 \times 10^{6}$ dalton subunits (actually measured as $2.64 \pm$ $0.1 \times 10^{6}$ by electrophoresis in a mercurial gel). The mobility of this sample corresponded to an apparent molecular weight of $4.2 \times 10^{6}$.

Thus, we believe that the $52 S$ RD-114 RNA 

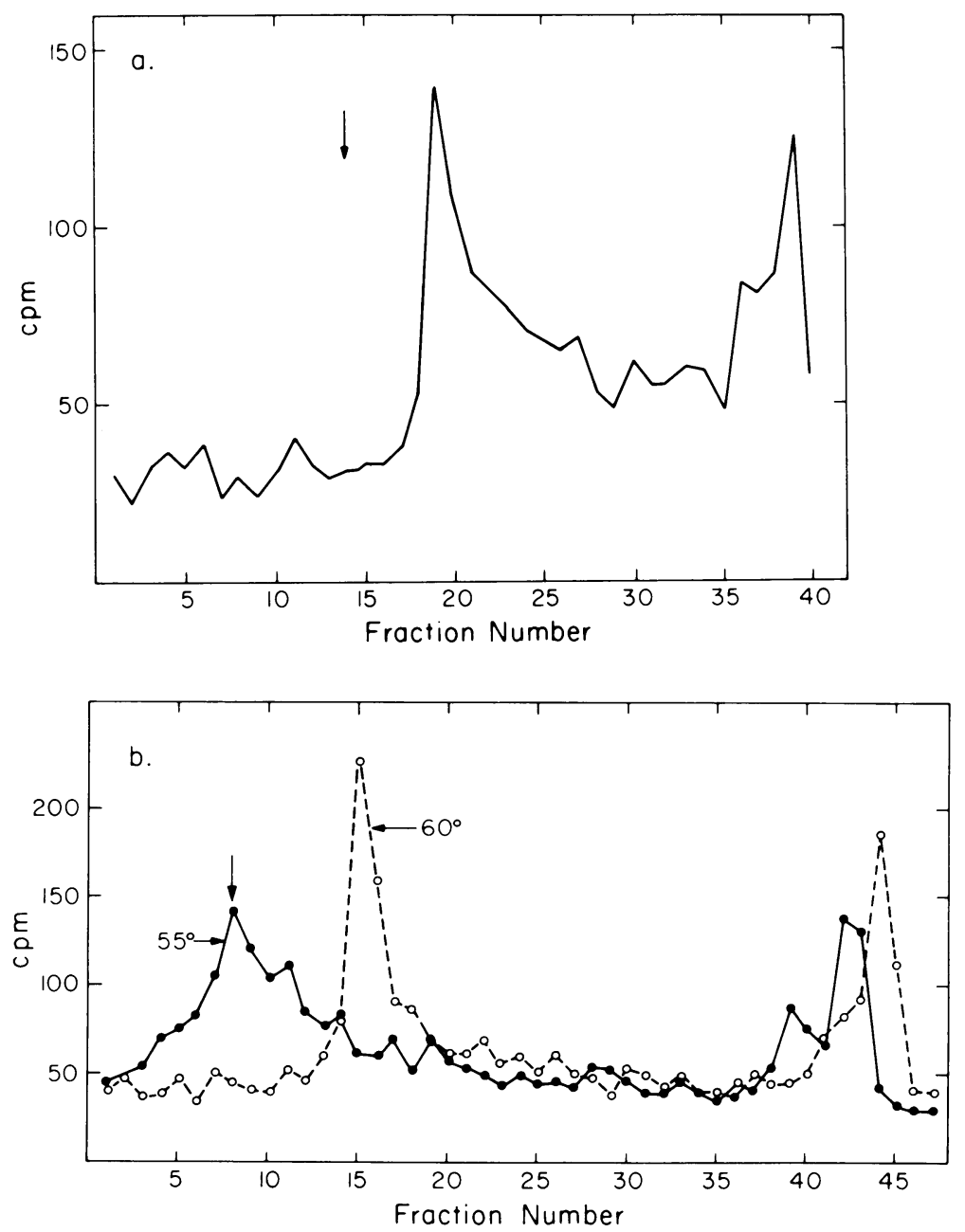

Fig. 8. Electrophoretic gel patterns. Electrophoresis is from left to right. (a) RD-114 RNA in a $5 \mathrm{mM}$

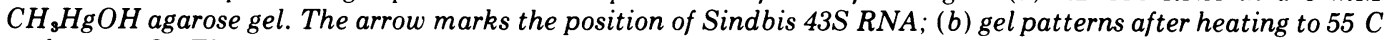
and to $60 \mathrm{C}$. Electrophoresis is in electrophoresis buffer at $22 \mathrm{C}$. The arrow is the migration position of unlabeled 52S RD-114 directly from an NTE gradient, as detected by ethidium bromide staining.

with a molecular weight of $5.7 \times 10^{6}$ and its half-size subunit with a molecular weight of 2.8 $\times 10^{6}$ show anomalously low electrophoretic velocities due to relatively extended configurations, as compared to HeLa $28 \mathrm{~S}$ rRNA and Sindbis RNA in the nondenaturing electrophoresis buffer. The data presented here therefore fix the melting temperature of the central $\mathrm{RE}$ feature, which is mainifested by dissociation of $52 S$ RNA into half-size subunits, as between 55 and $60 \mathrm{C}$ in the $65 \%(\mathrm{U}+\mathrm{F}), 0.06 \mathrm{M}$ cation solvent.

As reported in Materials and Methods, the melting temperature of calf thymus DNA in the same solvent was measured as $33 \mathrm{C}$ in an optical melting experiment.

\section{DISCUSSION}

Figure 10 summarizes our observations of the structure and properties of RD-114 RNA. The high-molecular-weight component extracted from the virion has a sedimentation coefficient of $52 S$ and a molecular weight of $5.74 \pm 0.17 \times$ $10^{6}$. It contains a characteristic secondary structure feature that we describe as the central RE with a molecular weight of about $0.3 \times 10^{6}$. The rest of the molecule is mainly single stranded, but there are two loops at the symmetrical positions around the RE and with the dimensions indicated in Fig. 10.

The $5.74 \times 10^{6}$ dalton molecule can be dissociated into half-size molecules by suffi- 
ciently denaturing conditions (methylmercuryglyoxal, or thermal dissociation in urea-formamide). The RE dissappears upon dissociation. We presume, that there is some sort of a base-paired structure between the two subunits giving rise to the RE (Fig. 10). By using a gel electrophoresis assay, we have concluded that

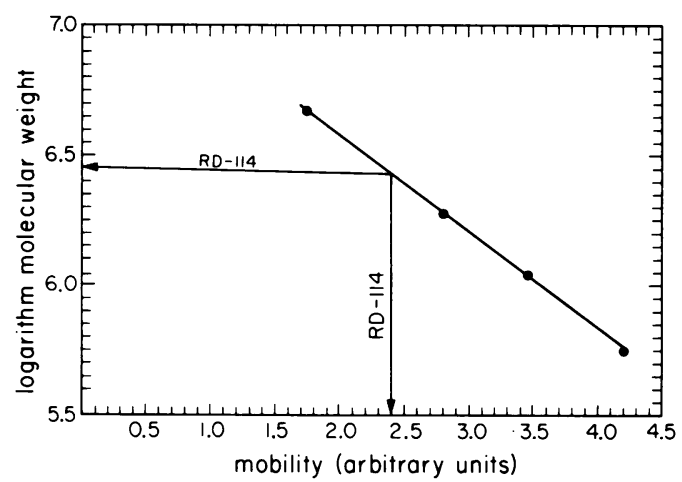

FIG. 9. A plot of RNA electrophoretic mobility in 5 $\mathrm{mM} \mathrm{CH} \mathrm{HgOH}_{\mathrm{s}} \mathrm{H.8 \%}$ agarose gels as a function of molecular weight. Marker RNAs, indicated by the filled circles, are $16 S$ and $23 S$ E. coli $r R N A, 28 S \mathrm{HeLa}$ rRNA, and Sindbis virus RNA with respective molecular weights of $0.56,1.10,1.90$, and 4.67 megadaltons. The mobility and interpolated molecular weight of RD-114 RNA are shown. the melting temperature for dissociation into half-size molecules in $65 \%(\mathrm{U}+\mathrm{F}), 0.06 \mathrm{M}$ univalent cation, is between 55 and $60 \mathrm{C}$. By comparison with the melting temperature of $31 \mathrm{C}$ for calf thymus DNA in the same solvent, we estimate that the melting temperature of the $\mathrm{RE}$ is 108 to $113 \mathrm{C}$ in an aqueous electrolyte containing $0.2 \mathrm{M} \mathrm{Na}^{+}$. The data collated by Kallenbach (8) on the melting temperature of duplex RNAs as a function of their base composition would then suggest that, if the RE is a simple RNA duplex, its base composition is about $63 \%$ guanosine plus cytosine.

W. Bender at this laboratory has developed and applied a method of electron microscope mapping of polyadenylic acid [poly (A)] stretches on polynucleotides by hybridization with poly (dT) attached to duplex simian virus 40 circles (as an electron microscope label) (W. Bender, personal communication). This method, which is based on a suggestion by J. Carbon, is an extension of one previously reported (6). Bender finds that there are poly (A) stretches on both outside termini of the $5.74 \times$ $10^{6} \mathrm{RD}-114$ molecule. We presume that the poly(A) stretches are located at the 3 '-termini of the half-size subunits; therefore the two 5 'termini are contained within the RE (Fig. 10). Note that the observation of a poly(A) stretch at
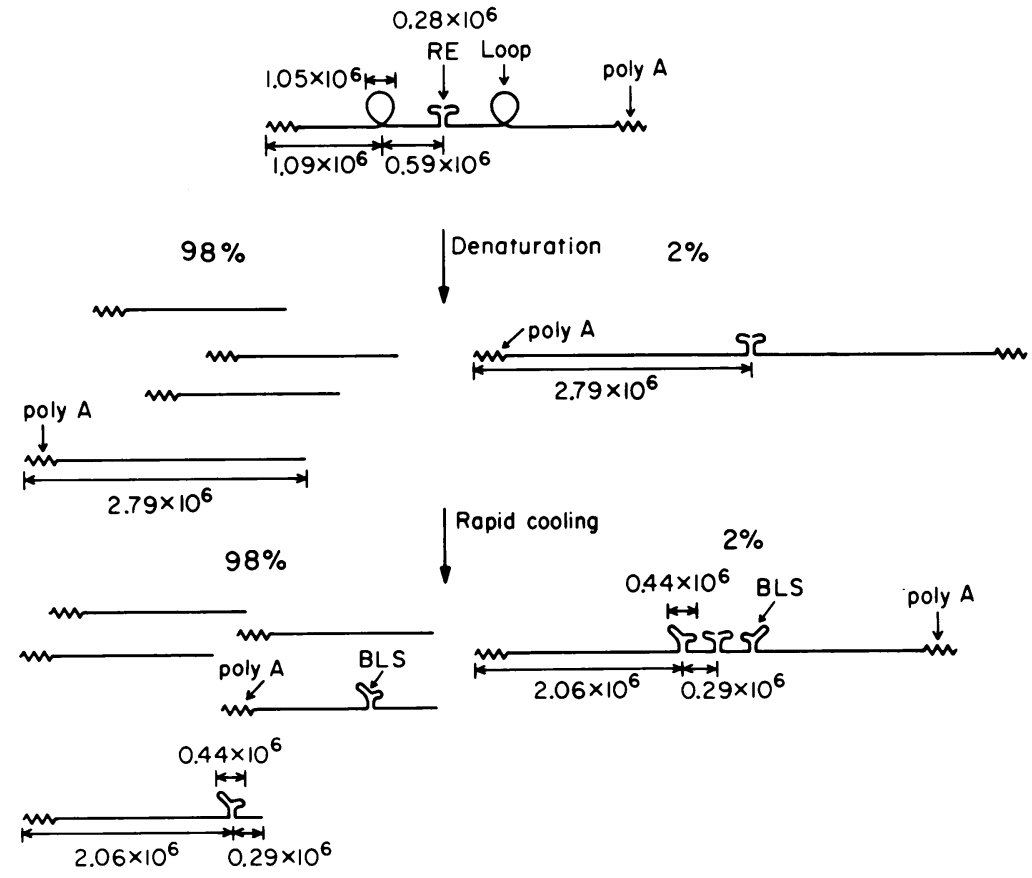

Fig. 10. Structure and interconversion between the several forms of RD-114 RNA described in the text (molecular weights in daltons are shown, and are based on electron microscopy length measurements). 
both of the outside ends demands that the 5.74 $\times 10^{6}$ dalton molecule be composed of two subunits, if poly(A) stretches occur only at $3^{\prime}$ ends.

We wish to note at this point that in our earlier preliminary reports $(9,10)$ we drew the tentative conclusion that the $5.74 \times 10^{6}$ dalton molecule was one continuous polynucleotide chain. We now believe that the conclusion was incorrect. At that time we also failed to notice the reproducible presence of the loop structures. It should also be noted that J. L. East et al. (2) had reported that the sedimentation coefficient of the high-molecular weight-component of RD-114 RNA, as extracted from the virion, was $50 \mathrm{~S}$ and that thermal dissociation in aqueous electrolyte solution led to the formation of $28 S$ subunits, all in approximate agreement with our present interpretations.

When RD-114 RNA, in 65\% $(\mathrm{U}+\mathrm{F})$, is heated to temperatures above $60 \mathrm{C}$ and then quenched on ice so that the loops disappear a new secondary structure feature, the BLS, is observed. This feature is close to the center, but a few molecules are observed that contain both the BLS and the RE (Fig. 10). This observation strongly suggests that the BLS is a distinct sequence and not part of the RE. The quantitative dimensions indicate that the BLS involves some sequence closer to the center than the two loops, but also include some sequences just within the loop (Fig. 10).

In spreadings at room temperature from $70 \%$ $(\mathrm{U}+\mathrm{F})$, almost all full length traceable molecules show the two loops symmetrically disposed around the RE. In $80 \%(U+F)$, about $50 \%$ of the loops are seen. A simple interpretation of these results is that the loop is held together by short complementary sequences which are about $50 \%$ melted in $80 \%(\mathrm{U}+\mathrm{F})$ at room temperature. If a loop is not present, the RNA appears to be a simple single strand in this region; i.e., the BLS is not seen. After heating and cooling in $65 \%(U+F)$, the BLS is seen. Since the BLS involves sequences closer to the center of the molecule than is the loop and sequences within the loop, and since the BLS is not seen when a loop is present, we tentatively conclude that the formation of the BLS requires an interaction between sequences within the loop with sequences closer to the center. An alternative possibility is that the loop structure is somehow held together by an additional low-molecular-weight molecule; the BLS cannot form until this molecule is removed by thermal dissociation.

We propose that two $2.8 \times 10^{6}$ molecules of RD-114 RNA are joined together at their $5^{\prime}$

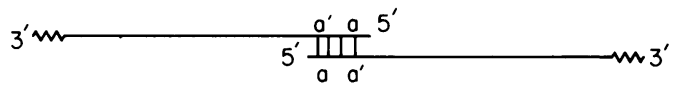

Fig. 11. Simplest possible structure for two RNA strands held together by anti-parallel base pairing at their $5^{\prime}$ ends. If the two strands are identical, each one must contain $a$ and its complement $a^{\prime}$ as indicated.

ends to form the $\mathrm{RE}$ feature. Watson-Crick base pairing requires that the two strands be oriented antiparallel with respect to each other. In the simplest case, this would lead to a linear structure at the junction of the two strands (Fig. 11). We have been unable to conceive of any simple, antiparallel scheme of base pairing between two strands that would lead to a Y-or T-shaped structure. The possibility that an additional low-molecular-weight RNA component is involved in the cohesion within the RE should also be considered. Since the RNA had been extracted by treatment with phenol, sodium dodecyl sulfate, and Pronase, it is unlikely (but not excluded) that any proteins are involved in the cohesion.

We observe that: (i) the molecular weight of the two $2.8 \times 10^{6}$ subunits into which the $52 S$ RD-114 RNA dissociates are identical within experimental error, as indicated by a single sharp peak in both the electron microscope length histogram and the gel electrophoresis pattern of the dissociated subunits; (ii) all the secondary structure features observed in these two subunits are identical in position and shape; (iii) both subunits contain a poly(A) stretch at the end.

One simple interpretation of these results is that the $52 S \mathrm{RD}-114$ molecule is a dimer consisting of two identical subunits, joined together somehow at their $5^{\prime}$ ends within the RE. These observations are consistent with results for the RNA from other tumor viruses, indicating that the 60 to $70 S$ complex contains two or three subunits of molecular weight in the range $2.5 \times 10^{6}$ to $3.3 \times 10^{6}$, and that these several subunits are identical in sequence (M. A. Baluda, M. Shoyab, P. D. Markham, R. Wans, and W. N. Drohan, Cold Spring Harbor Symp. Quant. Biol., in press; H. Delius, P. Duesberg, and W. Mangel, Cold Spring Harbor Symp. Quant. Biol., in press; Duesberg, P. K. Vogt, M. Lai, and K. Beeman, Cold Spring Harbor Symp. Quant. Biol., in press).

\section{ACKNOWLEDGMENTS}

This research has been supported by contracts NO-1CP-43306 and PH 43-68-1030 within the Virus-Cancer Program of the National Cancer Institute. We thank Welcome Bender for permission to quote his unpublished poly(A) mapping results. We also thank James Casey for helpful discussions. J.M.B. is the recipient of a Helen Hay Whitney Fellowship. 


\section{LITERATURE CITED}

1. Davis, R., M. Simon, and N. Davidson. 1971. Electron microscopic heteroduplex methods for mapping regions of base sequence homology, p. 413-428. In L. Grossman and K. Moldave (ed.), Methods in enzymology, vol. 21. Academic Press Inc., New York.

2. East, J. L., J. E. Knesek, P. T. Allen, and L. Dmochowski. 1973. Structural characteristics and nucleotide sequence analysis of genomic RNA from RD-114 virus and feline RNA tumor viruses. J. Virol. 12:1085-1091.

3. Filbert, J. E., R. M. McAllister, M. O. Nicolson, and R. V. Gilden. 1974. RD-114 virus, infectivity assay by measurements of DNA polymerase activity and virus group specific antigens. Proc. Soc. Exp. Biol. Med. 145: $366-370$.

4. Forsheit, A. B., N. Davidson, and D. B. Brown. 1974. An electron microscope heteroduplex study of the ribosomal DNAs in Xenopus laevis and Xenopus mulleri. J. Mol. Biol. 90:301-314.

5. Gruenwedel, D. W., and N. Davidson. 1966. Complexing and denaturation of DNA by methylmercuric hydroxide. J. Mol. Biol. 21:129-144.

6. Hsu, M. T., H. J. Kung, and N. Davidson. 1973. An electron microscope study of Sindbis virus RNA. Cold Spring Harbor Symp. Quant. Biol. 38:843-950.

7. Inman, R. B., and M. Schnös. 1970. Partial denaturation of thymine-and 5-bromouracil-containing $\lambda$ DNA in alkali. J. Mol. Biol. 49:93-98.

8. Kallenbach, N. R. 1968. Theory of thermal transitions in low molecular weight RNA chains. J. Mol. Biol. $37: 445-466$
9. Kung, H. J., J. M. Bailey, N. Davidson, M. O. Nicolson, and R. M. McAllister. 1974. Structure and molecular length of the large subunits of RD-114 viral RNA. J. Virol. 14:170-173.

10. Kung, H. J., J. M. Bailey, N. Davidson, P. Vogt, M. O. Nicolson, and R. M. McAllister. 1974. Electron microscope studies of tumor virus RNA. Cold Spring. Harbor Symp. Quant. Biol. 39:827-834.

11. Robberson, D., Y. Aloni, G. Attardi, and N. Davidson. 1971. Expression of the mitochondrial genome in HeLa cells. XI. Size determination of mitochondrial ribosomal RNA by electron microscopy. J. Mol. Biol. 60:473-484.

12. Sharp, P. A., B. Sugden, and J. Sambrook. 1973. Detection of two restriction endonuclease activities in $\mathrm{Hae}$. mophilus parainfluenza using analytical agarose ethidium bromide electrophoresis. Biochemistry 12:30553063.

13. Simpson, R. B. 1963. Association constants of methylmercuric and mercuric ions with nucleosides. J. Am. Chem. Soc. 86, 2059-2065.

14. Trávnicěk, M., and Riman, J. 1973. Subunits of oncornavirus high-molecular-weight RNA. I. Stepwise converstion of $60 S$ AMV RNA to subunits. Biochem. Biophys. Res. Commun. 53:217-223.

15. Wellauer, P. K., and I. B. Dawid. 1973. Secondary structure maps of RNA: processing of HeLa ribosomal RNA. Proc. Natl. Acad. Sci. U.S.A. 70:2827-2831.

16. Wellauer, P. K., I. B. Dawid, D. E. Kelley, and R. P. Perry. 1974. Secondary structure of mouse L-cell ribosomal RNA and variations in processing pathway. J. Mol. Biol. 89:397-407. 